Abstracta Iranicacta Iranica

Revue bibliographique pour le domaine irano-aryen

Volume 27 | 2006

Comptes rendus des publications de 2004

\title{
«Le prophète Jérémie et le Psautier ». Transeuphratène, 27 (2004), pp. 69-88.
}

\section{Astrid Nunn}

\section{(2) OpenEdition}

1 Journals

\section{Édition électronique}

URL : http://journals.openedition.org/abstractairanica/5710

DOI : 10.4000/abstractairanica.5710

ISSN : 1961-960X

Éditeur :

CNRS (UMR 7528 Mondes iraniens et indiens), Éditions de l'IFRI

\section{Édition imprimée}

Date de publication : 15 mai 2006

ISSN : 0240-8910

\section{Référence électronique}

Astrid Nunn, « «Le prophète Jérémie et le Psautier ». Transeuphratène, 27 (2004), pp. 69-88. », Abstracta Iranica [En ligne], Volume 27 | 2006, document 75, mis en ligne le 02 janvier 2007, consulté le 25

septembre 2020. URL : http://journals.openedition.org/abstractairanica/5710 ; DOI : https://doi.org/ 10.4000/abstractairanica.5710

Ce document a été généré automatiquement le 25 septembre 2020.

Tous droits réservés 
« Le prophète Jérémie et le Psautier

». Transeuphratène, 27 (2004), pp. 69-88.

\section{Astrid Nunn}

1 L'A. présente des correspondances linguistiques entre le livre de Jérémie et le Psautier. Ces deux écrits d'époque achéménide semblent s'être influencés mutuellement et non en sens unique.

INDEX

Thèmes : 3.2.1. Elam

\section{AUTEURS}

ASTRID NUNN

Université de Munich 